\title{
Antibacterial activity, antioxidant potential, total phenolic and flavonoids of three plant species of Rubiaceae from Banggai Island, Indonesia
}

\author{
PRAPTIWI $^{1 \bullet}$, DIAH SULISTIARINI ${ }^{1}$, ERSALIANY NURUL PRATIWI QODRIE $^{1}$, DENI SAHRONI ${ }^{2}$ \\ ${ }^{1}$ Research Center for Chemistry, Indonesian Institute of Sciences. Gd. 452 Bldg, Jalan puspitek serpong Gate, Muncul, Kec. Serpong, Kota Tangerang \\ Selatan, Banten 15314 "email: praptiwip@yahoo.com \\ ${ }^{2}$ Research Center for Biology, Indonesian Institute of Sciences. J1. Raya Jakarta-Bogor Km. 46 Cibinong, 16911
}

Manuscript received: 23 March 2021. Revision accepted: 22 April 2021.

\begin{abstract}
Praptiwi, Sulistiarini D, Qodrie ENP, Sahroni D. 2021. Antibacterial activity, antioxidant potential, total phenolic and flavonoids of three plant species of Rubiaceae from Banggai Island, Indonesia. Biodiversitas 22: 2773-2778. The present study was carried out to study the antioxidant and antibacterial potential of different plant parts (stems, leaves, and fruit) of the family Rubiaceae (Timonius celebicus, Psychotria celebica, Gardenia mutabilis) collected from the Banggai Islands. Screening of antibacterial activity against Staphylococcus aureus and Escherichia coli and antioxidant potential was carried out by Thin Layer ChromatographyBioautography. Determination of IC50 and Minimum Inhibitory Concentration (MIC) was carried out by microdilution in a 96-well microplate. Total phenolic and total flavonoid content was determined by the colorimetric method. Total phenolic (TPC) and total flavonoid content (TFC) was varied from 29.78-380.99 $\mathrm{mg}$ GAE/g extract and 105.61-841.18 $\mathrm{mg}$ QE/g extract, respectively. The antioxidant capacity of three plant species was varied from moderate to very strong. Antioxidant Activity Index (AAI) was found more affected by TFC than TPC. The antibacterial activity of the extract against E. coli was weak, while some extracts have moderate antibacterial activity against $S$. aureus.
\end{abstract}

Keywords: Rubiaceae, Banggai Island, antioxidant capacity, antibacterial

\section{INTRODUCTION}

Rubiaceae is a plant family, commonly known for coffee or madder plants. It comprises more than 600 genera and 13.000 species and is mainly distributed in the tropics (Anon 2020). The species diversity of Rubiaceae is ranked fourth among Angiosperms (Davis et al. 2009). Some plant species of this family are used in our everyday life. Some plants are economically important such as coffee, cinchona, noni, gambier, gardenia, and Ixora, due to their chemical properties. These plants are widely used as ornamental, food, and remedy in traditional medicine (Karou et al. 2011). Bioactive metabolites produced by plants of the family Rubiaceae have great pharmacological potential (Martins and Nunez 2015).

The natural chemical compounds and their pharmacological properties from some Rubiaceae plants include iridoids, anthraquinones, triterpenes, indole alkaloids, and other varying alkaloid subclasses (Martins and Nunez,2015). Among plants of Rubiaceae, coffee (Coffea arabica) is the most economically important and widely known. Caffeine is the main compound in coffee (Coffea arabica) with pharmacological properties as a bronchodilator, diuretic, vasoconstrictor, and central nervous system stimulant (Simões et al. 2004). Cinchona ledgeriana (Rubiaceae) is a rich source of quinine that is active against malaria and responsible for synthetic antimalarial developments (Viegas et al. 2006).

Due to the increased antibiotic resistance, and the risk of infectious disease spread is also increasing. Therefore, it is necessary to search for new antimicrobial compounds. In addition, there is also evidence of increasing degenerative disease associated with free radicals. Free radicals have been associated with the development of several diseases, including cancer, neurodegeneration, and inflammatory diseases (Ferguson 2010). Oxidative stress occurs when there are excessive free radicals in the body cells that caused imbalance with antioxidants and lead to the emergence of several diseases in the long term, including cellular damage, aging, cancer, and hepatic, neurodegenerative, cardiovascular, and renal disorders (Losada-Barreiro et al. 2017).

Banggai Islands are located in Central Sulawesi, Indonesia. Information on the use of the plant of the family Rubiaceae from Banggai is still very limited. Therefore, the present study was conducted to determine the total phenolic, total flavonoids, antioxidant and antibacterial activity of methanol extracts of some important plants of family Rubiaceae from Banggai.

\section{MATERIALS AND METHODS}

\section{Sampling sites}

Three species of Rubiaceae were collected from Banggai Islands, Central Sulawesi, Indonesia (Figure 1). Timonius celebicus was collected from Tinangkung Village $\left(1^{\circ} 26^{\prime} 27.2^{\prime \prime} \mathrm{S}, 123^{\circ} 20^{\prime} 19.5^{\prime \prime} \mathrm{E}\right)$, Gardenia mutabilis was 
collected from Saiyong Village $\left(1^{\circ} 24^{\prime} 22.0^{\prime \prime} \mathrm{S}\right.$, $123^{\circ} 19^{\prime} 50.0^{\prime \prime}$ E), while Psychotria celebica was also collected from Saiyong Village (1 $\left.{ }^{\circ} 22^{\prime} 43.1^{\prime \prime} \mathrm{S}, 123^{\circ} 18^{\prime} 17.8^{\prime \prime} \mathrm{E}\right)$.

\section{Plant materials}

Three plant species of Rubiaceae, namely Timonius celebicus, Psychotria celebica, and Gardenia mutabilis, were collected from the Banggai Islands. The plant parts (leaves, stems, and fruits) were separated, cleaned, and dried under sunlight. After drying, the plant parts were grounded into a fine powder 4 and stored it at $4^{\circ} \mathrm{C}$ for further use.

\section{Extraction}

The plant powder was extracted with methanol by maceration thrice. The filtrate was concentrated under reduced pressure by a rotary evaporator. The extract was soaked for 24 hours, and then the filtrate was filtered and concentrated. The remaining solvent was removed with nitrogen and stored at $-20^{\circ} \mathrm{C}$ for further analysis.

\section{Determination of total phenolics (Ismail et al. 2012)}

Sixty-eight $\mu \mathrm{L}$ of the extract at the concentration of 1 $\mathrm{mg} / \mathrm{mL}$ was added with $68 \mu \mathrm{L}$ of $50 \%$ Folin-Ciolcalteu reagent and then vortex for 1 minute. Then $1,364 \mu \mathrm{L}$ of Sodium carbonate $\left(\mathrm{Na}_{2} \mathrm{CO}_{3}\right) 2 \%$ was added to the mixture and incubated for 30 minutes. Sixty-eight $\mu \mathrm{L}$ of gallic acid with a concentration range of $0.031-0.250 \mathrm{mg} / \mathrm{mL}$ was used as standard. The standard absorbance of gallic acid and extract was measured at a wavelength of $750 \mathrm{~nm}$ with a UV-VIS spectrophotometer. The results are expressed as gallic acid equivalent $\mathrm{mg} / \mathrm{g}$ of extract.

\section{Determination of total flavonoids (Zou et al. 2004)}

Determination of total flavonoids was performed by the colorimetry method. Total $150 \mu \mathrm{L}$ of samples $(1 \mathrm{mg} / \mathrm{mL})$ and quercetin standards with a concentration range of $0.03125-0.5000 \mathrm{mg} / \mathrm{mL}$ in ethanol p.a was added with 600 $\mu \mathrm{L}$ aqua dest, $45 \mu \mathrm{L} \mathrm{NaNO} \mathrm{Na}_{2} \%$, and incubated for 6 minutes. After incubation, the mixture was added with 45 $\mu \mathrm{L}$ of $10 \% \mathrm{AlCl}_{3}$ solution and left for $6 \mathrm{~min}$. The mixture was added with $600 \mu \mathrm{l}$ of $\mathrm{NaOH}$ solution (4\%) and added with aqua dest to reach the final volume of $1.5 \mathrm{~mL}$. The mixture was vortexed and incubated for $15 \mathrm{~min}$ at room temperature under dark conditions. The solution was measured using a spectrophotometer with a wavelength of $510 \mathrm{~nm}$. Results were expressed in $\mathrm{mg}$ quercetin equivalent/g extract.

\section{Determination of antioxidant activity by TLC- DPPH Bioautography}

Screening of antioxidant activity was carried out by thin-layer chromatography (TLC)-Bioautography (Dot-Blot and Develop). Dot-Blot: Samples (10 $\mu \mathrm{L}$ in a concentration of $10 \mathrm{mg} / \mathrm{mL}$ ) was transferred onto a TLC-silica plate (Merck, F254) and cold-dried. TLC plate was sprayed with diphenyl picrylhydrazyl (DPPH) solution in methanol. After 30 minutes, the clear zone around the samples was observed. The yellowish-white area indicated that samples have antioxidant activity. Color intensity showed the antioxidant capacity of samples.

\section{Antibacterial screening by TLC-bioautography}

TLC-Bioautography was performed antibacterial for screening of the methanol extracts against Staphylococcus aureus (Ina-CC B4) and Escherichia coli (Ina-CC B5). Ten $\mu \mathrm{L}$ of the extract $(10 \mathrm{mg} / \mathrm{mL})$ was spotted on the TLC plate and immersed in the bacterial suspension. Plates were incubated under humid conditions for $24 \mathrm{~h}$ at $37^{\circ} \mathrm{C}$. After incubation, plates were sprayed with an aqueous solution of iodonitrotetrazolium $(4 \mathrm{mg} / \mathrm{mL})$. The appearance of the white area indicates that extract can inhibit the growth of bacteria. On other plates, the spotted extracts were developed with chloroform: methanol: water (C:M: W) $6: 4: 1$. After the plates were developed, the plates were immersed in the bacterial suspension and incubated at $37^{\circ} \mathrm{C}$ for $24 \mathrm{~h}$. The plates were then sprayed with iodonitrotetrazolium solution. White bands of spots indicate the active antibacterial compounds.

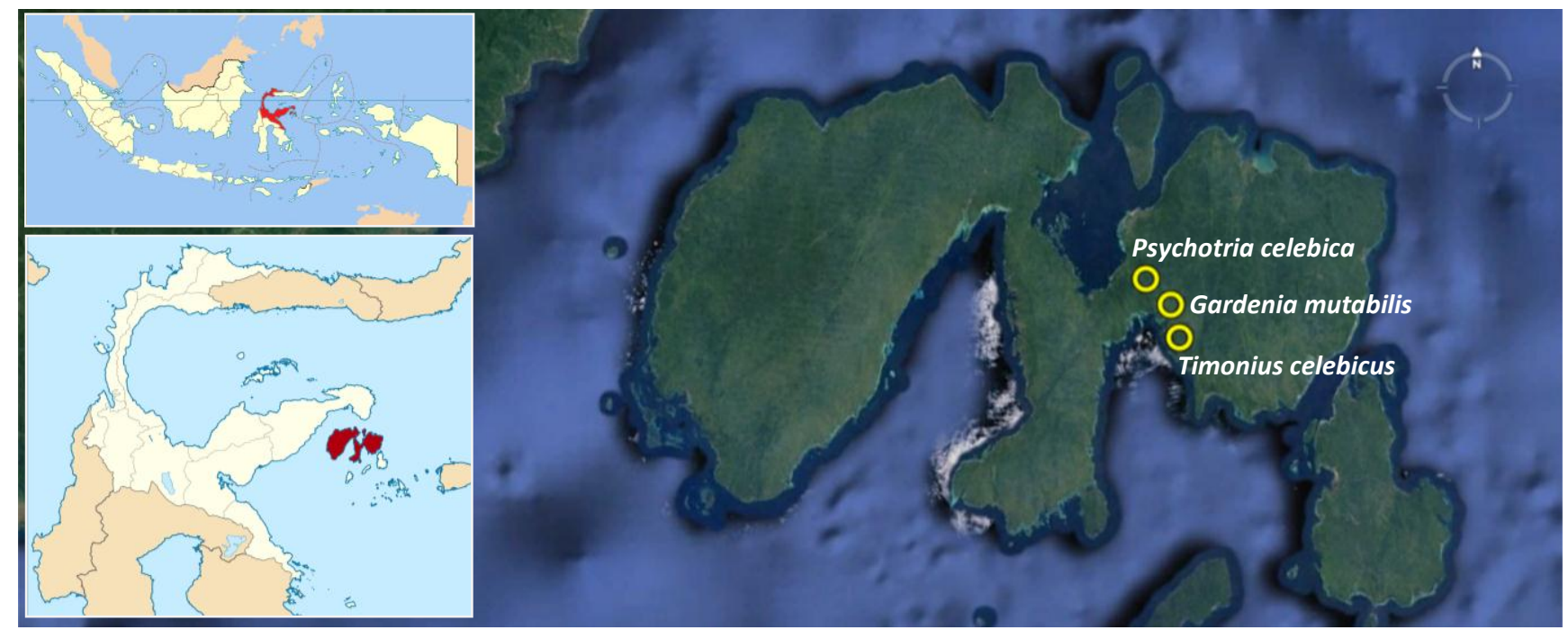

Figure 1. Sampling sites of three species of Rubiaceae in Banggai Islands, Central Sulawesi, Indonesia 


\section{Determination of Minimum Inhibitory Concentration (MIC)}

Minimum Inhibitory Concentration (MIC) is used to classify the antibacterial potential of the extract. It was carried out by microdilution on a 96-well microplate with a lid. Wells in row A were introduced with $100 \mu \mathrm{L}$ Mueller Hinton Broth (MHB) and $90 \mu \mathrm{L}$ of sterilized distilled water. Wells in row $\mathrm{B}$ to $\mathrm{H}$ was introduced with $100 \mu \mathrm{L}$ Mueller Hinton Broth. After filling the wells with MHB, the wells in row A were added with $10 \mu \mathrm{L}$ of extract $(10.24$ $\mathrm{mg} / \mathrm{mL}$ DMSO) and homogenized. Serial dilution was performed by taking out $100 \mu \mathrm{L}$ of the mixture in row A and transferred it to row B that has been filled with $100 \mu \mathrm{L}$ Mueller Hinton Broth in the same column. The same procedure was continued to the last row. At the last row, $100 \mu \mathrm{L}$ of the mixture was discarded. All work was carried out aseptically in the laminar airflow. After finish diluting, the plates were incubated at $37^{\circ} \mathrm{C}$ for $24 \mathrm{~h}$. After completing incubation, each well was added with $10 \mu \mathrm{L}$ iodonitrotetrazolium chloride (INT) $(4 \mathrm{mg} / \mathrm{mL})$. Minimum Inhibitory Concentration (MIC) was determined at the lowest concentration that does not change color after INT addition.

\section{Determination of IC50 value for antioxidant activity and antioxidant activity index (AAI)}

Determination of IC50 for antioxidant activity by DPPH method was carried out by serial dilution in a 96well microplate. Each well was filled with $100 \mu \mathrm{L}$ methanol p.a. except well in row A was filled with $195 \mu \mathrm{L}$ methanol p.a. Wells in row A was added with $5 \mu \mathrm{L}$ of extract $(20.48 \mathrm{mg} / \mathrm{mL})$ and homogenized. Serial dilution was carried out by transferring $100 \mu \mathrm{L}$ of the mixture from row $\mathrm{A}$ into row $\mathrm{B}$ in the same column. It was done to the last row, and at the last row, $100 \mu \mathrm{L}$ of the mixture was discarded. After finish diluting, each well was added with $100 \mu \mathrm{L}$ of DPPH $(61.5 \mu \mathrm{L} / \mathrm{mL})$ and incubated for $90 \mathrm{~min}$ under dark conditions at room temperature. After incubation, the absorbance of the extract was determined using a microplate reader (Varioscan Flash, Thermo Scientific) at $517 \mathrm{~nm}$. The following equation was used to calculate the inhibitory concentration:

$$
\mathrm{IC}(\%)=\left(\mathrm{A}_{\mathrm{DPPH}} 100 \%-\mathrm{A}_{\text {sample }}\right) * 100 / \mathrm{A}_{\text {sample }}
$$

Where:

IC: inhibitory concentration

$\mathrm{A}_{\mathrm{DPPH}}$ 100\%: : Absorbance of DPPH

$A_{\text {sample: }}$ Absorbance of the sample

A linear regression curve of the inhibitory percentage against extract concentration was drawn to determine the IC50 (El-Abbassi et al. 2012).

Antioxidant Activity Index (AAI) was calculated by the following equation:

$\mathrm{AAI}=$ final concentration of DPPH/IC50 value

\section{Data analysis}

Duncan's multiple ranges performed the analysis of variance for TPC and TFC values (DMRT) tests using SPSS 16.0. The experiment was performed in triplicate. It is expressed as mean $\pm \mathrm{SD}$.

\section{RESULTS AND DISCUSSION}

\section{Total phenolic and flavonoids content of three species of Rubiaceae from}

Total phenolic and flavonoids content of methanol extract of T. celebicus, $P$. celebica, and G. mutabilis collected from Banggai Island were presented in Table 1 . The results in Table 1 showed that there are variations in total phenolic content (TPC) and total flavonoid content (TFC), even in the same plant species but in different parts of the plant. The highest TPC (380.99 mg GAE/g extract) and TFC (841.18 $\mathrm{mg} \mathrm{QE} / \mathrm{g}$ extract) was found in the $T$. celebicus stem extract that is significantly higher $(\mathrm{p}<0.05)$ from other extracts. The lowest TPC was in G. mutabilis leaves extract, while the lowest TFC was in G. mutabilis stem extract.

\section{Determination of antioxidant activity by Thin Layer Chromatography (TLC)-Bioautography}

Screening of antioxidant activity of three plant species Rubiaceae was performed by Diphenyl pycril hydrazil (DPPH) method using TLC-Bioautography The bioautogram results of antioxidant activity (Figure 2.) showed that each extract develops yellowish-white bands. It indicated that each extract contains chemical compounds that might have antioxidant activity as DPPH free radical scavengers. Each extract may contain more than one antioxidant active chemical compounds.

\section{Determination of the antibacterial activity of three species of Rubiaceae}

Preliminary screening of antibacterial activity was carried out by TLC-Bioautography against Staphylococcus aureus Ina-CC B4 and Escherichia coli Ina-CC B3. Preliminary screening of antibacterial activity of three species of Rubiaceae against $S$. aureus and E. coli showed that some extracts could inhibit the growth of bacteria. It showed by halo zone formation. Figure 3 showed that $S$. aureus more susceptible to Rubiaceae extract.

Table 1. Total phenolic and total flavonoids content of methanol extract of three species of Rubiaceae

\begin{tabular}{lll}
\hline Sample (extract) & \multicolumn{1}{c}{ TPC } \\
& (mg GAE/g extract) $^{2}$ & $\begin{array}{c}\text { TFC } \\
\text { (mg QE/g extract }\end{array}$ \\
\hline T. celebicus leaves & $258.76^{\mathrm{b}} \pm 0.132$ & $731.39^{\mathrm{b}} \pm 0.210$ \\
T.celebicus stem & $380.99^{\mathrm{a}} \pm 0.132$ & $841.180^{\mathrm{a}} \pm 0.000$ \\
P.celebica bark & $131.690^{\mathrm{e}} \pm 0.024$ & $288.910^{\mathrm{e}} \pm 0.182$ \\
P.celebica leaves & $157.400^{\mathrm{d}} \pm 0.083$ & $288.910^{\mathrm{e}} \pm 0.083$ \\
P.celebica fruit & $239.420^{\mathrm{c}} \pm 0.000$ & $505.060^{\mathrm{c}} \pm 0.189$ \\
G.mutabilis leaves & $89.486^{\mathrm{f}} \pm 9.659$ & $426.820^{\mathrm{d}} \pm 0.091$ \\
G.mutabilis stem & $39.924^{\mathrm{g}} \pm 26.835$ & $105.610^{\mathrm{g}} \pm 0.139$ \\
G.mutabilis leaves & $29.778^{\mathrm{g}} \pm 2.315$ & $123.760^{\mathrm{f}} \pm 2.315$ \\
\hline
\end{tabular}

Notes: TPC: Total phenolic content; TFC: Total flavonoids content; GAE: gallic acid equivalent; $\mathrm{QE}$ : quercetin equivalent 


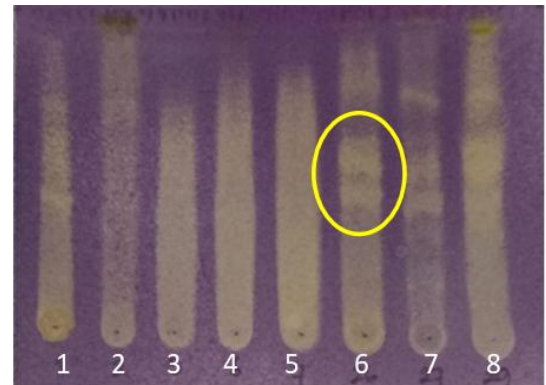

Figure 2. Bioautogram of antioxidant activity of Rubiaceae methanol extract of three plant species developed with chloroform: methanol: water $(6: 4: 1)$, observed $30 \mathrm{~min}$ after sprayed with $2 \%$ DPPH solution in methanol. Yellowish white bands indicated antioxidant activity. The order from left to right was similar to Table 1 .

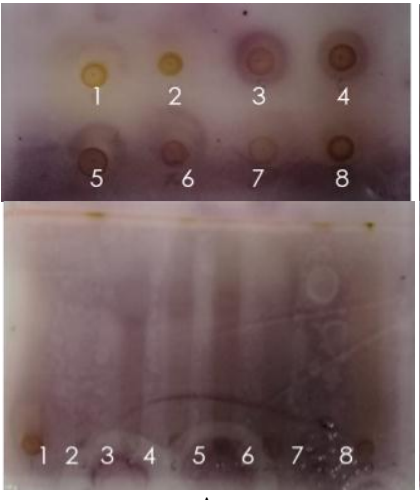

A

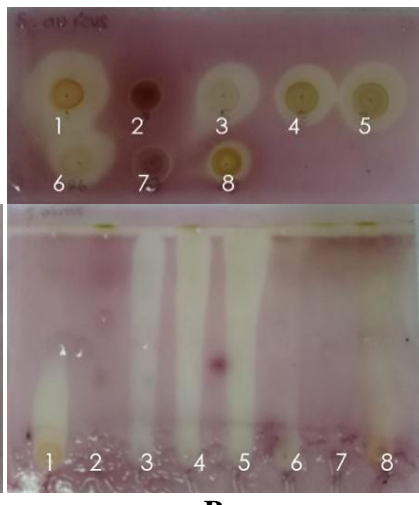

B
Figure 3. Bioautogram of antibacterial activity of three species of Rubiaceae against $E$. coli (A) and $S$. aureus (B). Dot blot method (top), develop extract by chloroform: methanol: water (6:4:1).

\section{Determination of IC50 value and AAI of methanol extract of three species of Rubiaceae}

Based on the results of the AAI value of the extract, three plant species of Rubiaceae collected from Banggai had moderate to very powerful antioxidant activity. The highest AAI was obtained from G. mutabilis leaves extract; it was significantly higher $(\mathrm{p}<0.05)$ than other extracts. Different parts of the plant may have a different category of antioxidant activity. Leaves extract of $P$. celebica had moderate antioxidant activity, while its leaves and fruit extract have powerful antioxidant activity (Table 2).

\section{Determination of MIC of methanol extract of three species of Rubiaceae}

Minimum Inhibitory Concentration of the extract showed that all extracts were categorized as weak antibacterial activity against $E$. coli. However, there are 4 extracts that have moderate antibacterial activity against $S$. aureus, which are $T$. celebicus leaves extract, $P$. celebica leaves, bark, and fruit extracts (Table 3).

\section{Correlation between TPC, TFC, and antioxidant activity}

The correlation between TPC, TFC, and antioxidant activity was carried out by Pearson correlation coefficient. Table 4 showed that total phenolic content has a weak correlation to AAI related to antioxidant activity. Total flavonoids content (TFC) showed a moderate correlation to the antioxidant activity of the extract. TFC has more effect than TPC on the antioxidant activity of Rubiaceae extract in this study.

\section{Discussion}

Rubiaceae is one of the most widely used plant families in traditional medicine due to its bioactive compounds with pharmacological potential (Karou et al. 2011; Martins and Nunez 2015). One of the chemical components in Rubiaceae is flavonoids and phenolic derivatives (Martins and Nunez 2015). Results in Table 1 showed variations in TPC and TFC. It showed that TPC and TFC in T. celebicus stem extract were significantly higher than those in leaves extract.

Table 2. IC50 value and AAI of methanol extract of three species of Rubiaceae

\begin{tabular}{llll}
\hline Sample (extract) & $\begin{array}{c}\text { IC50 } \\
(\boldsymbol{\mu g} / \mathbf{m L})\end{array}$ & \multicolumn{1}{c}{ AAI } & $\begin{array}{c}\text { Category of } \\
\text { antioxidant }\end{array}$ \\
\hline T. celebicus leaves & 10.33 & $3.390^{\mathrm{ab}} \pm 0.800$ & Very powerful \\
T.celebicus stem & 7.64 & $4.197^{\mathrm{ab}} \pm 0.540$ & Very powerful \\
P.celebica bark & 4586 & $0.673^{\mathrm{b}} \pm 0.020$ & Moderate \\
P.celebica leaves & 12.62 & $2.384^{\mathrm{ab}} \pm 0.362$ & Very powerful \\
P.celebica fruit & 11.40 & $2.667^{\mathrm{ab}} \pm 0.462$ & Very powerful \\
G.mutabilis leaves & 51.67 & $5.724^{\mathrm{a}} \pm 5.511$ & Very powerful \\
G.mutabilis stem & 5.17 & $0.736^{\mathrm{b}} \pm 0.042$ & Moderate \\
G.mutabilis leaves & 41.24 & $0.602^{\mathrm{b}} \pm 0.065$ & Moderate \\
\hline N.
\end{tabular}

Note: Values in each column with the different letters are significantly different $(\mathrm{P}<0.05)$. Statistical criteria of AAI values for extract follows: weak $<0.5<$ Moderate $<1<$ Strong $<2<$ very strong (Schreer and Godoy 2009).

Table 3. Minimum Inhibitory Concentration of methanol extract of three species of Rubiaceae

\begin{tabular}{lllll}
\hline \multirow{2}{*}{ Sample (extract) } & $\begin{array}{c}\text { MIC } \\
(\boldsymbol{\mu g} / \mathbf{m L})\end{array}$ & Category & $\begin{array}{c}\text { MIC } \\
(\boldsymbol{\mu} \mathbf{g} / \mathbf{m L})\end{array}$ & Category \\
\cline { 2 - 4 } & \multicolumn{1}{c}{ S.aureus } & & $\boldsymbol{E}$.coli & \\
\hline T. celebicus leaves & 256 & Moderate & $>256$ & Weak \\
T.celebicus stem & $>256$ & Weak & $>256$ & Weak \\
P.celebica bark & 256 & Moderate & $>256$ & Weak \\
P.celebica leaves & 256 & Moderate & $>256$ & Weak \\
P.celebica fruit & 256 & Moderate & $>256$ & Weak \\
G.mutabilis leaves & $>256$ & Weak & $>256$ & Weak \\
G.mutabilis stem & $>256$ & Weak & $>256$ & Weak \\
G.mutabilis leaves & $>256$ & Weak & $>256$ & Weak \\
\hline
\end{tabular}

Table 4. Pearson correlations coefficient (r) between TPC, TFC values, and Antioxidant Activity Index (AAI)

\begin{tabular}{llll}
\hline Variables & $\begin{array}{l}\text { Pearson } \\
\text { Coefficient }{ }^{\circledR}\end{array}$ & Correlation & Category \\
\cline { 2 - 3 } & \multicolumn{2}{c}{ AAI } & \\
\hline TPC value & 0.360 & weak \\
TFC value & $0.504^{*}$ & moderate \\
\hline
\end{tabular}

Note $(*)$ : Correlation is significant at the 0.05 level (2-tailed) 
Sembiring et al. (2018) reported that phytochemical compounds in the different plant parts might differ, affecting their pharmacological activity. Secondary metabolites, including TFC and TPC, were affected by many factors, such as soil, irrigation, and climatic conditions, affect phenolic concentrations and other secondary metabolites (Chandra et al. 2014). Phenolic and flavonoids have important biological activities such as antitumor (Murakami et al. 2004), anti-inflammatory (Araujo and Leon 2001), and antioxidative activity (Ghasemzadeh et al. 2011) that are beneficial for human health. The antioxidative activity of phenolic and flavonoids was due to their ability as free radical scavengers (Shahidi et al. 1992), and reducing agents (Ghasemzadeh and Ghasemzadeh 2011), singlet oxygen quenchers, and hydrogen donors (Rice-Evans et al. 1996; Ramarathnam et al. 1997). Phenolic compounds can protect lipids from peroxidation and inhibit enzymes from oxidizing (Cos et al. 1998).

Assessment of antioxidants was performed by DPPH free radical scavenging activity using TLC-Bioautography as it is a fast and straightforward method. The results showed several white-yellowish spots or bands on the TLC plate's purple background after spraying with DPPH solution in methanol. Changes color of purple-blue of DPPH to yellow due to the unpaired electrons of DPPH is paired with electrons of antioxidant compounds to become reduced DPPH-H (diphenyl picryl hydrazine) (Cai et al. 2003) which decreases the absorption (Dehpour et al. 2007). The antioxidant capacity of extract was determined by IC50 value and antioxidant activity index (AAI). Table 2 showed that 5 extracts have potent antioxidant activity, while 3 extracts have moderate antioxidant activity. The antioxidant activity positively correlates with TPC and TFC (Table 4.), and the TFC has more effect (moderate correlation) on antioxidant activity than TPC (weak correlation) caused by hydroxyl groups in flavonoids (Das and Pereira 1990). However, structure differences in flavonoids affect the antioxidant capacity (Wojdylo et al. 2007).

TLC-Bioautography was also used to determine the qualitative antibacterial activity of extracts. Bioautography can detect antimicrobial compounds rapidly. It allows detecting antimicrobial activity directly on the TLC plate by forming a white zone (Navarro 1998). Purple background on the TLC plate was caused by the conversion of tetrazolium salt to intensely colored formazan by dehydrogenase enzymes in living microorganisms (Grzelak et al. 2013). A microdilution assay determined the sensitivity differences of extracts and bacteria to determine the minimum inhibitory concentration (MIC). The results in Table 3 showed that 4 extracts have moderate activity against $S$. aureus, while all extracts have weak antibacterial activity against $E$. coli. It seems that $S$. aureus was more sensitive to the extracts. The differences in the sensitivity between S. aureus (Gram-positive bacteria) and E. coli (Gram-negative bacteria) might be due to cell wall structure differences. Gram-negative bacteria are more resistant to antibacterial components because of the periplasmic space and lipopolysaccharide layer (Koohsari et al. 2015)

In conclusion, the extracts of three plant species of Rubiaceae (T. celebicus, P. celebica, and G. mutabilis) collected from the Banggai Islands contain bioactive compounds with antibacterial or antioxidant activity. However, these extracts have better activity as antioxidants than antibacterial. Therefore, bioactive compounds from these extracts should be isolated and purified in further study.

\section{ACKNOWLEDGEMENTS}

The authors thank Florentina Indah Windradi for collecting Rubiaceae samples. There is no conflict of interest regarding the publication of this paper. The main contributor to this manuscript is $\mathrm{P}$ (the first author).

\section{REFERENCES}

Anon. 2020. Rubiaceae plant family. Britannica. https://www.britannica.com/plant/Rubiaceae

Araujo CAC, Leon LL. 2001. Biological activities of Curcuma longa L. Mem Inst Oswaldo Cruz 96 (5): 723-728. DOI: 10.1590/s007402762001000500026

Cai Y, Sun M, Corke H. 2003. Antioxidant activity of betalains from plants of the Amaranthaceae. J Agric Food Chem 51: 2288-2294. DOI: $10.1021 /$ jf030045u.

Chandra S, Khan S, Avula B, Lata H, Yang MH, ElSohly MA, Khan IA. 2014. Assessment of total phenolic and flavonoid content, antioxidant properties, and yield of aeroponically and conventionally grown leafy vegetables and fruit crops: A Comparative Study. Evid Based Compl Alternat Med. 2014: 253875. DOI: 10.1155/2014/253875.

Cos P, Ying L, Calomme M, Hu JP, Cimanga K, Poel BV, Pieters L, Vlietinck AJ, Berghe DV. 1998. Structure-activity relationship and classification of flavonoids as inhibitors of xanthine oxidase and superoxide scavengers. J Nat Prod 61 (1): 71-76.

Das NP, Pereira TA. 1990. Effects of flavonoids on thermal autooxidation of palm oil: structure-activity relationship. J. Amer Oil Chem Soc 67: 255-258.

Davis AP, Govaerts R, Bridson DM, Ruhsam M, Moat J, Brummitt NA. 2009. A global assessment of distribution, diversity, endemism and taxonomic effort in the Rubiaceae. Ann Missouri Bot Gard 96 (1): 6878. DOI: $10.3417 / 2006205$.

Dehpour AA, Ebrahimzadeh MA, Seyed Fazel N, Seyed Mohammad N. 2009. Antioxidant activity of the methanol extract of Ferula assafoetida and its essential oil composition. Grasasy Aceites 60: 405-412. DOI: 10.3989/gya.

El-Abbassi A, Kiai H, Hafidi A. 2012. Phenolic profile and antioxidant activities of olive mill wastewater. Food Chem 132: 406-412. 10.1016/j.foodchem.2011.11.013.

Ferguson LR. 2010. Chronic inflammation and mutagenesis. Mutat Res 690: 3-11. DOI: 10.1016/j.mrfmmm.2010.03.007.

Ghasemzadeh A, Ghasemzadeh N. 2011. Flavonoids and phenolic acids: Role and biochemical activity in plants and human. J Med Plants Res 5 (31): 6697-6703. DOI: 10.5897/JMPR11.1404.

Ghasemzadeh A, Jaafar HZE, and Rahmat A. 2011. Effects of solvent type on phenolics and flavonoids content and antioxidant activities in two varieties of young ginger (Zingiber officinale Roscoe) extracts. J Med Plant Res 5 (7): 1147-1154.

Grzelak EM, Jesionek W, Majer-Dziedzic B, Choma IM. 2013. Application of the novel direct bioautography tests for analysis of antimicrobials: A Review, Special Section. J AOAC Intl 96: 11671174. DOI: 10.5740/jaoacint.SGEGrzelak.

Ismail J, Runtuwene MRJ, Fatimah F. 2012. Penentuan total fenolik dan uji aktivitas antioksidan pada biji dan kulit buah pinang yaki (Areca vestiaria Giseke). Jurnal Ilmiah Sains 12 (2): 84-88. DOI: 10.35799/jis.12.2.2012.557. [Indonesian] 
Karou SD, Tchacondo T, Ilbuodo DP, Simpore J. 2011. Sub-Saharan Rubiaceae: A review of their traditional uses, phytochemistry and biological activities. Pak J Biol Sci 14 (3): 149-169. DOI: 10.3923/pjbs.2011.149.169

Koohsari H, Ghaemi EA, Sheshpoli MS, Jahedi M, Zahiri M. 2015. The investigation of antibacterial activity of selected native plants from North of Iran. J Med Life 8 (2): 38-42.

Losada-Barreiro S, Bravo-Díaz C. 2017. Free radicals and polyphenols: The redox chemistry of neurodegenerative diseases. Eur J Med Chem 133: 379-402. DOI: 10.1016/j.ejmech.2017.03.061

Martins D, Nunez CV. 2015. Secondary metabolites from Rubiaceae species. Molecules 20: 13422-13495. DOI: 10.3390/molecules200713422.

Murakami A, Miyamoto M, and Ohigashi H. 2004. Zerumbone, an antiinflammatory phytochemical, induces expression of proinflammatory cytokine genes in human colon adenocarcinoma cell lines. Biofactors 21: 95-101. DOI: 10.1002/biof.552210118.

Ramarathnam N, Ochi H, Takeuchi M. 1997. Antioxidant defense system in vegetable extracts, in Natural Antioxidants, Chemistry, Health Effects and Applications, F. Shahidi, Ed. AOCS Press, Champaign, IL, USA.

Rice-Evans CA, Miller NJ, Bolwell PG, Bramley PM, and Pridham JB 1995. The relative antioxidant activities of plant-derived polyphenolic flavonoids. Free Radic Res 22 (4): 375-383. DOI: 10.3109/10715769509145649

Sembiring EN, Elya B, Sauriasari R. 2018. Phytochemical screening, total flavonoid and total phenolic content, and antioxidant activity of different parts of Caesalpinia bonduc (L.) Roxb Pharmacog J 10 (1): 123-127.

Shahidi F, Janitha PK, Wanasundara PD. 1992. Phenolic antioxidants. Crit Rev Food Sci Nutr 32 (1): 67-103. DOI: 10.1080/10408399209527581.

Simões CMO, Schenkel EP, Gosmann G, Mello JCP, Mentz LA, Petrovick PR. 2004. Farmacognosia: Da planta ao medicamento, 6th eds. UFSC University Press: Florianópolis, Brazil.

Viegas C, Bolzani VS, Barreiro EJ. 2006. Os produtos naturais e a química medicinal moderna. Quim. Nova 29: 326-337. DOI: 10.1590/S0100-40422006000200025.

Wojdyło A, Oszmia'nski J, Czemerys R. 2007. Antioxidant activity and phenolic compounds in 32 selected herbs. Food Chem 105 (3): 940949. DOI: 10.1016/j.foodchem.2007.04.038.

Zou Y, Lu Y and Wei D. 2004. Antioxidant activity of flavonoid-rich extract of Hypericum perforatum L in vitro. J Agric Food Chem 52 (16): 5032-2039. DOI: $10.1021 /$ jf049571r 